\title{
Coating of Medical-Grade PVC Material with ZnO for Antibacterial Application
}

\author{
Huaxiang Lin ${ }^{1}$, Luyao Ding ${ }^{1}$, Weihua Deng ${ }^{1}$, Xuxu Wang ${ }^{1 *}$, Jinlin Long ${ }^{1}$, Qun Lin ${ }^{2}$ \\ ${ }^{1}$ Research Institute of Photocatalysis, Fujian Provincial Key Laboratory of Photocatalysis, \\ State Key Laboratory Breeding Base, Fuzhou University, Fuzhou, China \\ ${ }^{2}$ First Affiliated Hospital, Fujian Medical University, Fuzhou, China \\ Email: *xwang@fzu.edu.cn
}

Received June 7, 2013; revised July 7, 2013; accepted July 17, 2013

Copyright (C) 2013 Huaxiang Lin et al. This is an open access article distributed under the Creative Commons Attribution License, which permits unrestricted use, distribution, and reproduction in any medium, provided the original work is properly cited.

\begin{abstract}
The $\mathrm{ZnO}$ sol well-crystallized was prepared by the sol-gel method. The $\mathrm{ZnO}$ films were coated on medical-grade PVC surface by the improved organic-inorganic interfacial adhesion method. The physical and photocatalytic properties of the samples were characterized by XRD, SEM, DRS spectra and measured by the photodegradation reaction of Rhodamine B (RhB) and anti-bacteria for Escherichia coli (E. coli), respectively. The results show that pretreatment of PVC by the mix solution of THF-PVC helps to improve the amount and adhesion strength of ZnO suspension to PVC surface. The photocatalytic and antibacterial properties of the THF-ZnO/PVC film are better than that of the $\mathrm{ZnO} / \mathrm{PVC}$ and neat PVC. Under UV irradiation, the THF-ZnO/PVC film shows the best antibacterial properties with $99 \%$ kill rate of bacteria.
\end{abstract}

Keywords: ZnO; PVC; Photocatalysis; Antibacterial

\section{Introduction}

The increasing use of polymer materials such as polyethylene, polyurethanes, and poly (vinyl chloride) (PVC) in the hospital care has led to a concomitant increase in the incidence of biomaterial-related infections (BRI) [1]. Adhesion of bacteria to biomaterials led to the formation of biofilm on the surface, which plays a crucial role in the pathogenesis of the BRI [1-3]. The growth and production of biofilm protect the bacteria from the host defence mechanisms and external agents as the drug treatments $[1,2,4-7]$, which makes the cure of the bacterial infections quite difficult and requires either higher doses or more potent antibiotics.

In order to efficiently prevent or reduce biofilm formation, many efforts have been done to enhance the antibacterial properties of biomaterials. Some efforts such as modifying the physicochemical properties of biomaterial surface, coating with silver, azidation treatment, antibiotic impregnation into the polymer matrix, have been examined in recent years [8-12].

Recently, coating semiconductor photocatalyst on materials' surface for antibacterial activity has attracted great interest due to the following advantages when

"Corresponding author. compared with other methods: 1) excellent photocatalytic and antimicrobial activity, 2) nontoxicity and bio-compatibility, 3) strong physicochemical stability and durable antibacterial properties. The antibacterial mechanism of semiconductor photocatalysis is mainly based on its UV photoactive property. Taking $\mathrm{ZnO}$ as an example was shown in Equations (1)-(4) [13].

$$
\begin{aligned}
& \mathrm{ZnO}+h v \rightarrow \mathrm{e}^{-}+h^{+} \\
& \mathrm{h}^{+}+\mathrm{OH}^{-} \rightarrow \bullet \mathrm{OH} \\
& \mathrm{e}^{-}+\mathrm{O}_{2} \rightarrow \mathrm{O}_{2} \bullet^{-} \\
& \mathrm{O}_{2} \bullet^{-}+2 \mathrm{H}^{+}+\mathrm{e}^{-} \rightarrow \mathrm{H}_{2} \mathrm{O}_{2}
\end{aligned}
$$

When $\mathrm{ZnO}$ was exposed to UV light with the wavelength less than $388 \mathrm{~nm}$, the semiconductor surface generated valence band holes and conduction band electrons as in Equation (1). The holes could react with water or surface hydroxyls $\left(\mathrm{H}_{2} \mathrm{O} / \mathrm{OH}^{-}\right)$to generate hydroxyl radicals $(\mathrm{HO} \bullet)$, while conduction band electrons reacted with adsorbed molecular oxygen $\left(\mathrm{O}_{2}\right)$ to generate superoxide radical $\left(\mathrm{O}_{2} \bullet\right)$. The radicals $\left(\mathrm{O}_{2} \bullet\right.$ and $\left.\mathrm{HO} \bullet\right)$ can destroy and shrink bacterial cells by reacting with the organism of bacterial cells in the photocatalytic process [14, 15]. Among various oxides semiconductor photocatalysis, 
$\mathrm{TiO}_{2}$ and $\mathrm{ZnO}$ are generally considered to be the most suitable for antibacterial agents [15-18]. $\mathrm{TiO}_{2}$ film coated on different materials' surface is effective at killing bacteria and viruses under UV irradiation $[15,16]$. $\mathrm{ZnO}$ as antibacterial agents has been reported exhibiting higher antibacterial activity than other metal oxide nanoparticles [19]. It has supposed that $\mathrm{ZnO}$ not only kills bacteria under UV irradiation bacteria but also inhibits the bacterial growth under normal visible lighting conditions [20]. To extend the usage of antibacterial agents, many studies have been done to coat $\mathrm{ZnO}$ film on many materials' surface that was widely used in life such as glass, ceramic, stainless steel, polymer, and so on. In general, to obtain highly adherent and antibacterial activity of $\mathrm{ZnO}$ film, heating the materials that have been modified by $\mathrm{ZnO}$ film at high temperature is required. However, one of the main barriers to coat $\mathrm{ZnO}$ on polymer is the low heat resistance of polymer. Low heat resistance of polymer disables the routine coating method to be used to modify inorganic $\mathrm{ZnO}$ film on polymer.

Recently, organic-inorganic composite membrane by mixing inorganic and organic materials has been supposed to use because of its simplicity, mild conditions and stability $[21,22]$. In this work, a similar organic-inorganic interfacial adhesion method was used to coat $\mathrm{ZnO}$ film on polymer materials. First, suspension of well-crystallized $\mathrm{ZnO}$ was prepared by sol-gel at low temperature. Then, to improve the adhesion strength of $\mathrm{ZnO}$ to PVC, the mix solution of PVC and THF was used to pretreat the surface of PVC sheet. After pretreated by the mix solution of PVC and THF, PVC sheets were coated with $\mathrm{ZnO}$ film by dip-coating with suspension $\mathrm{ZnO}$. The photocatalytic and antibacterial activity of $\mathrm{ZnO}$ film was investigated. To evaluate the antibacterial activity after modified by $\mathrm{ZnO}$, the performance of $\mathrm{ZnO}$ film was compared with neat PVC under similar operating conditions.

\section{Materials and Methods}

\subsection{Material}

Medical-grade PVC sheets were purchased from Tyco Healthcare International Trading (Shanghai) Co., Ltd., and were washed with absolute alcohol before use. Escherichia coli were cultured at $37^{\circ} \mathrm{C}$ in Luria-Bertani (LB) medium ( $\mathrm{pH} 7.0$ ) containing tryptone $1 \%$, yeast extract $0.5 \%$, sodium chloride $1 \%$. When tested, the bacterial concentration was adjusted to the required concentration $\left(10^{4}-10^{5} \mathrm{cfu} / \mathrm{ml}\right)$. Other reagents were of analytical grade and used as received.

\subsection{Preparation of $\mathrm{ZnO}$ Sol}

$\mathrm{Zn}(\mathrm{Ac})_{2} \cdot 2 \mathrm{H}_{2} \mathrm{O}$ was dissolved in methanol to obtained a $0.075 \mathrm{M}$ solution of $\mathrm{Zn}$ (Ac). Ammonia was dropped into the solution to adjust the $\mathrm{pH}$ to 8 and then stirred the solution at $65^{\circ} \mathrm{C}$ for $2 \mathrm{~h}$ to obtain $\mathrm{ZnO}$ sol.

\subsection{Coating ZnO on PVC Surface}

The $\mathrm{ZnO}$ film was prepared by dip-coating method with $\mathrm{ZnO}$ suspension as precursor. The PVC sheets $(1.5 \times 4.5$ $\mathrm{cm})$ were pre-immersed in THF-PVC solution for $10 \mathrm{~s}$. Immediately, the PVC samples were dipped into $\mathrm{ZnO}$ colloidal sol and were slowly pulled out of the sol at a speed of $1200 \mathrm{~mm} / \mathrm{h}$ in an ambient atmosphere. The $\mathrm{ZnO}$ gel film on PVC were dried in an oven at $60^{\circ} \mathrm{C}$ for 30 min and then were dried at $120^{\circ} \mathrm{C}$ for $2 \mathrm{~h}$. After seven such coating steps, the transparent $\mathrm{ZnO}$ film on PVC were obtained. The PVC sheets without pretreatment were coated with $\mathrm{ZnO}$ under similar operating conditions for comparison. For ease of presentation, the $\mathrm{ZnO}$ film with pretreatment were labelled as $\mathrm{THF}-\mathrm{ZnO} / \mathrm{PVC}$ and that without pretreatment were labelled as $\mathrm{ZnO} / \mathrm{PVC}$.

\subsection{Structure and Morphology Characterizations}

The crystal structure of the sample was characterized by X-ray diffraction (XRD) (Bruker D8 Advance powder diffractometer). The scanning electron microscopy (SEM) was performed on a Philips XL30 ESEM system. The $\mathrm{UV}-\mathrm{V}$ is spectra were obtained in the diffuse reflection mode using a Carry 500 spectrometer at a resolution of 2 $\mathrm{nm}$. The spectra of the PVC, $\mathrm{ZnO} / \mathrm{PVC}$ and THF-ZnO/ PVC sheets were recorded in the ultraviolet and visible in the wavelength range from 250 to $800 \mathrm{~nm}$.

\subsection{Photocatalytic and Antibacterial Property}

\subsubsection{Photocatalytic Activity}

The photocatalytic activities of $\mathrm{PVC}, \mathrm{ZnO} / \mathrm{PVC}$ and THF-ZnO/PVC were determined by monitoring the degradation of organic dye Rhodamine $\mathrm{B}(\mathrm{RhB})$. A quartz tube reactor with condenser pipe was used and four 4W-UV lamps with wavelength at $365 \mathrm{~nm}$ were fixed around the reactor. The PVC sheets $(1.5 \times 4.5 \mathrm{~cm})$ were immersed in $20 \mathrm{ml}$ aqueous solution of $\mathrm{RhB}\left(1 \times 10^{-5}\right.$ $\mathrm{mol} / \mathrm{dm}^{3}$ ) and kept for $12 \mathrm{~h}$ in black prior to irradiation. The concentration of $\mathrm{RhB}$ at different irradiation times was monitored by Varian UV-260 spectrometer.

\subsubsection{Bacterial Adhension}

The neat PVC, $\mathrm{ZnO} / \mathrm{PVC}$ and THF-ZnO/PVC sheets were immersed in the aqueous solution of Escherichia coli (E. coli), and kept at $37^{\circ} \mathrm{C}$ for $24 \mathrm{~h}$. The sheets were taken out and rinsed gently with sterile phosphate buffered saline (PBS) to remove the non-adherent bacteria. Then, the bacteria adhered on the sheets were eluted into $5 \mathrm{ml}$ of sterile PBS in an ultrasonic cleaner for $5 \mathrm{~min}$. The number of the eluted bacteria was then determined 
by colony counts (CFU). The adherent number was expressed by the ratio of the total adherent bacterial to the area of the measured sample.

\subsubsection{Antibacterial Property}

$\mathrm{ZnO} / \mathrm{PVC}$ sheets $(2.5 \times 2.5 \mathrm{~cm})$ were placed on sterile plates, and then $0.5 \mathrm{ml}$ broth inoculated with $10^{4} \mathrm{cfu} / \mathrm{ml}$ of $E$. coli was added onto the surfaces. The samples were irradiated with an $8 \mathrm{~W} \mathrm{UV} \mathrm{lamp} \mathrm{(with} \mathrm{wavelength} \mathrm{at} 365$ $\mathrm{nm}$ ) for $150 \mathrm{~min}$. After irradiated, the sheets were rinsed with sterile phosphate buffered saline (PBS) and the number of viable bacteria was determined by colony counts (CFU). The blank PVC sample was also test for comparison. The antibacterial property of $\mathrm{PVC}, \mathrm{ZnO} /$ PVC and THF-ZnO/PVC was valued by the kill percentage, a ratio of the dead number of the bacterial to the initial number of the bacterial.

\section{Results and Discussion}

\subsection{Structure and Morphology}

The $\mathrm{ZnO}$ nanoparticles were prepared by simple sol-gel method. The size analysis of $\mathrm{ZnO}$ sol indicated that most of $\mathrm{ZnO}$ colloid particles are located in the range of 50 $70 \mathrm{~nm}$ (Figure 1). $\mathrm{ZnO}$ colloid particles were dried into powder at $120^{\circ} \mathrm{C}$ for X-ray diffraction (XRD) analysis. Several obvious peaks are observed at $2 \theta$ values at 31.6, $34.3,36.1,47.3,56.4,62.5$ and 67.7, which correspond to wurtzite structure of hexagonal $\mathrm{ZnO}$ [23] (Figure 2). No other phases are observed in the patterns, indicating that the sample that prepared by this method are pure wurtzite $\mathrm{ZnO}$.

Figure 3 shows the SEM images of neat PVC, $\mathrm{ZnO} / \mathrm{PVC}$ and THF-ZnO/PVC. The neat PVC surface is smooth with little flaws. After coated only with $\mathrm{ZnO}$ colloid, the morphology of $\mathrm{ZnO} / \mathrm{PVC}$ become rougher and a small $\mathrm{ZnO}$ nanostructure sheet spread on the $\mathrm{ZnO} / \mathrm{PVC}$ surface. However, when PVC were pretreated by THF-PVC solution and subsequently coated with $\mathrm{ZnO}$

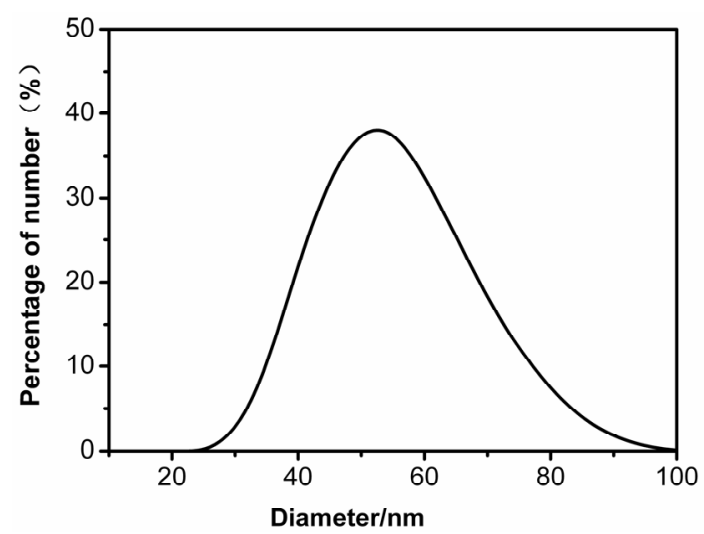

Figure 1. Size distribution of $\mathrm{ZnO}$ colloid particles.

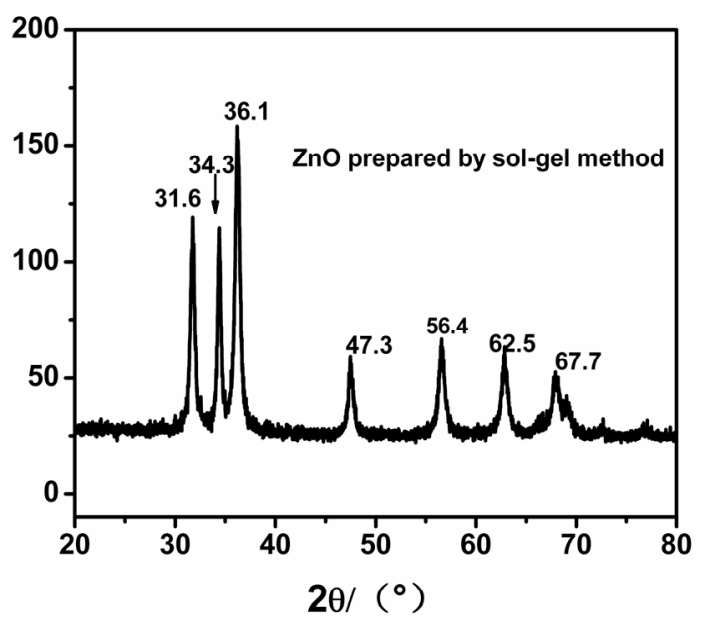

Figure 2. XRD spectra of $\mathrm{ZnO}$.
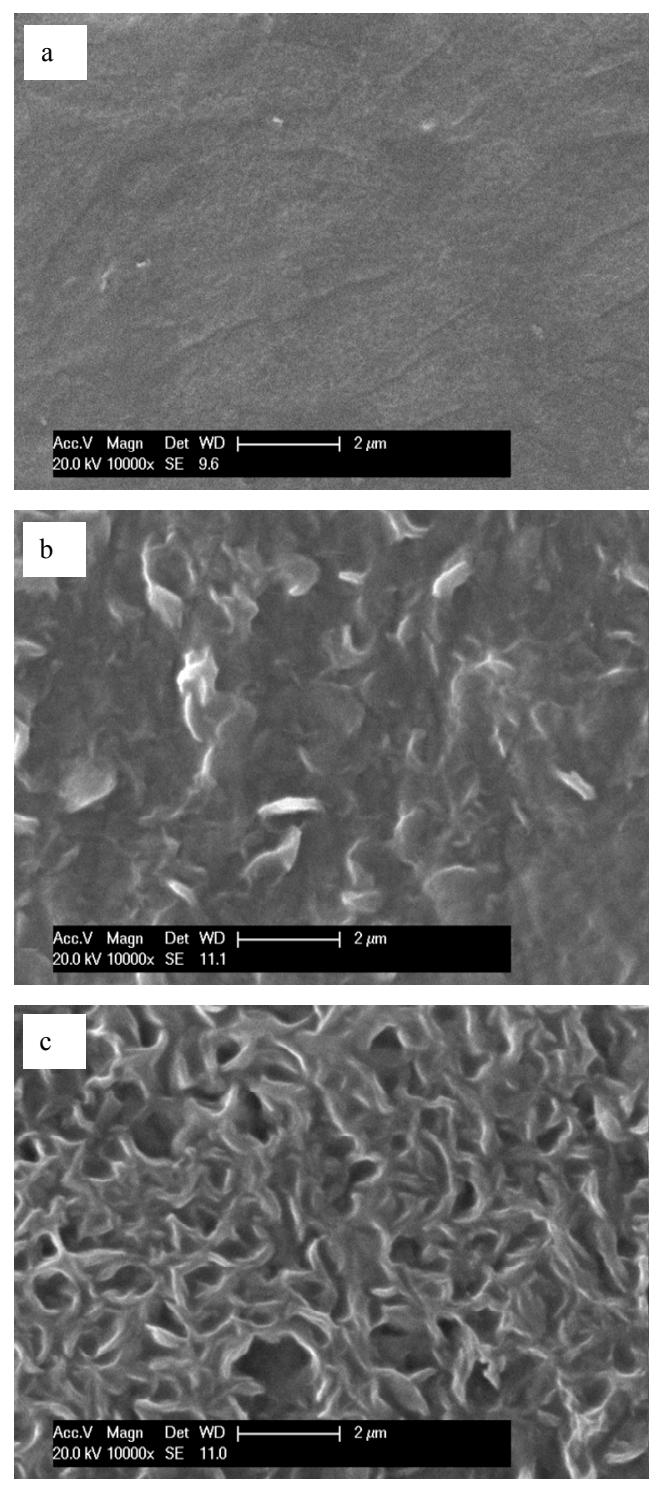

Figure 3. SEM images of different PVC surface; a) neat PVC; b) ZnO/PVC; THF-ZnO/PVC. 
colloid, many $\mathrm{ZnO}$ nanostructure sheets stacked on THF$\mathrm{ZnO} / \mathrm{PVC}$ surface closely and the surface of THF- $\mathrm{ZnO} /$ $\mathrm{PVC}$ was composed by irregularity cross-linked $\mathrm{ZnO}$ sheets. This result indicated that pretreated PVC by THFPVC solution improves the adherent amount of $\mathrm{ZnO}$ on PVC surface. The Optical absorption property of PVC, $\mathrm{ZnO} / \mathrm{PVC}$ and THF-ZnO/PVC were examined with UV$\mathrm{Vis}$ reflectance spectra (DRS), as shown in Figure 4. The DRS spectra show that $\mathrm{ZnO} / \mathrm{PVC}$ and THF-ZnO/PVC exhibit significant enhancement of light absorption in the $\mathrm{UV}$ region than nude $\mathrm{PVC}$, which is attributed to bandgap excitation of $\mathrm{ZnO}$. Another difference in the DRS spectra is that the absorption baseline of the resulting samples in visible light region is decrease in the order of $\mathrm{PVC}>\mathrm{ZnO} / \mathrm{PVC}>\mathrm{THF}-\mathrm{ZnO} / \mathrm{PVC}$. This is originnated from the transparent nature of the samples. $\mathrm{ZnO}$ deposited on PVC reduces transparency of PVC, which causes more of incident light reflect and consequently enhances the baseline absorption in visible light region. The more amount of $\mathrm{ZnO}$ coated on PVC, the lower baseline absorption of the sample.

\subsection{Photocatalytic Activity}

Figure 5 shows the change in photocatalytic conversions

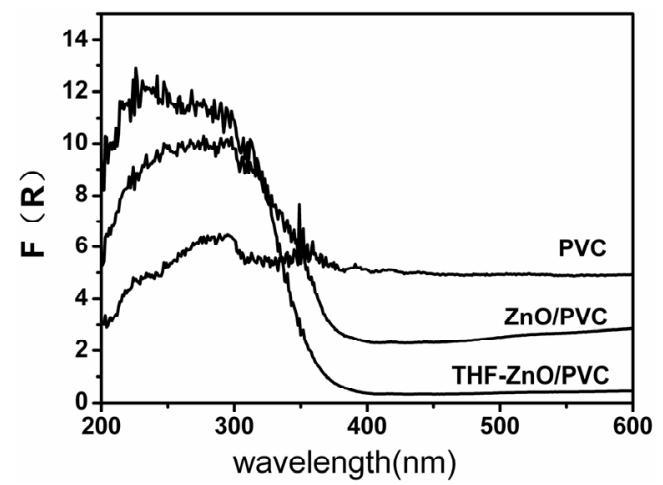

Figure 4. UV-vis diffuse reflectance spectra of PVC, ZnO /PVC and THF-ZnO/PVC.

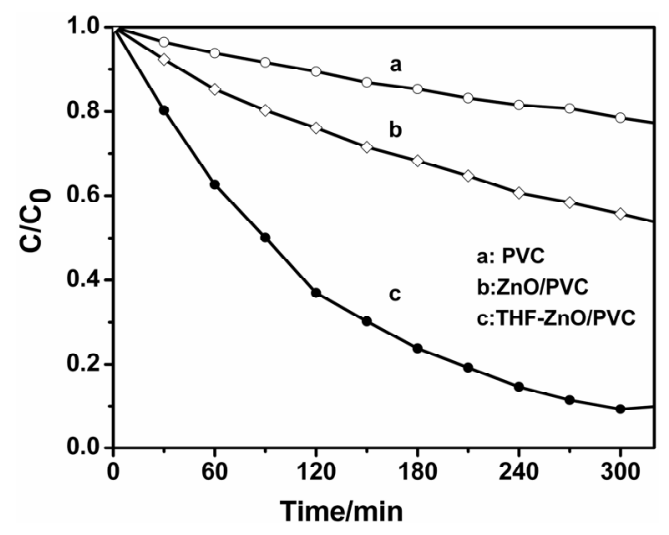

Figure 5. Photocatalytic degradation conversion of RhB on PVC, ZnO/PVC and THF-ZnO/PVC. of $\mathrm{RhB}$ with reaction time on the nude $\mathrm{PVC}, \mathrm{ZnO} / \mathrm{PVC}$ and THF-ZnO/PVC. As can been seen from these spectra, the nude PVC sheet exhibits no photocatalytic activity. Only about $25 \%$ of $\mathrm{RhB}$ are photodecomposed following about $300 \mathrm{~min}$ of illumination. The photocatalytic activity of $\mathrm{ZnO} / \mathrm{PVC}$ samples exhibit a little better than that of neat $\mathrm{PVC}$, with the conversion rate of $\mathrm{RhB}$ increases to about $50 \%$ of $\mathrm{RhB}$ upon about $300 \mathrm{~min}$ of illumination. The pretreatment of THF-PVC solution for PVC has much great effect on the photocatalytic activity of the resulting sample. As can be seen form spectra $\mathrm{c}$ in Figure 5, the degraded rate of $\mathrm{RhB}$ on THF-ZnO/PVC is greatly increased and about $90 \%$ of $\mathrm{RhB}$ are degraded upon about $300 \mathrm{~min}$ of illumination. The result shows that pretreatment of THF-PVC for PVC is beneficial for the coating of $\mathrm{ZnO}$ on PVC surface.

\subsection{Bacterial Adhesion and Sterilization Behavior}

Figure 6 shows the adherent number of $E$. coli to the surface of nude PVC, $\mathrm{ZnO} / \mathrm{PVC}$ and THF-ZnO/PVC under dark condition. After culture bacteria on the sample surface in dark for $18 \mathrm{~h}$, the number of $E$. coli adhered on nude PVC is similar to initial number of E. coli (Figure 6(d)), showing that the nude PVC material is inertial to prevent adhesion of bacterial. The adherent number of E. coli on $\mathrm{ZnO} / \mathrm{PVC}$ decreases a little when compared with that of nude PVC as shown in Figures 6(a) and (b), suggesting that coating $\mathrm{ZnO}$ on PVC helps to enhance antibacterial activity of PVC. Especially, when the PVC was pretreated with mix solution of THF-PVC and subsequently coated with $\mathrm{ZnO}$, the antibacterial activity of THF-ZnO/PVC increases greatly with the adherent number of E. coli is almost zero (Figure 6(c)). The result suggests that $\mathrm{THF}-\mathrm{ZnO} / \mathrm{PVC}$ can effective prevent the adhesion and growth of bacterial on PVC surface.

Figure 7 shows the kill percentage of E. coli on PVC, $\mathrm{ZnO} / \mathrm{PVC}$ and THF-ZnO/PVC under UV irradiation for 150 min. PVC exhibits no antibacterial activity under UV light. And $\mathrm{ZnO} / \mathrm{PVC}$ shows a little antibacterial activity with the survival ratio of $E$. coli on $\mathrm{ZnO} / \mathrm{PVC}$ is $46.8 \%$ after irradiation for $150 \mathrm{~min}$. However, the THF$\mathrm{ZnO} / \mathrm{PVC}$ exhibits stronger antibacterial property. More than $99 \%$ of the bacteria were killed under UV irradiation for $150 \mathrm{~min}$.

It has been reported that it is the photocatalytic property of metal oxide that is responsible for the excellent sterilization properties $[15,24]$. In other words, the higher the photocatalytic property, the higher the sterilization activity, and vice versa. This proposition was identified by the photocatalytic property and sterilization activity of $\mathrm{TiO}_{2}$ [15]. In the present work, the photocatalytic property and sterilization activity of THF-ZnO/PVC are much better than that of $\mathrm{ZnO} / \mathrm{PVC}$. The main reason is may be 

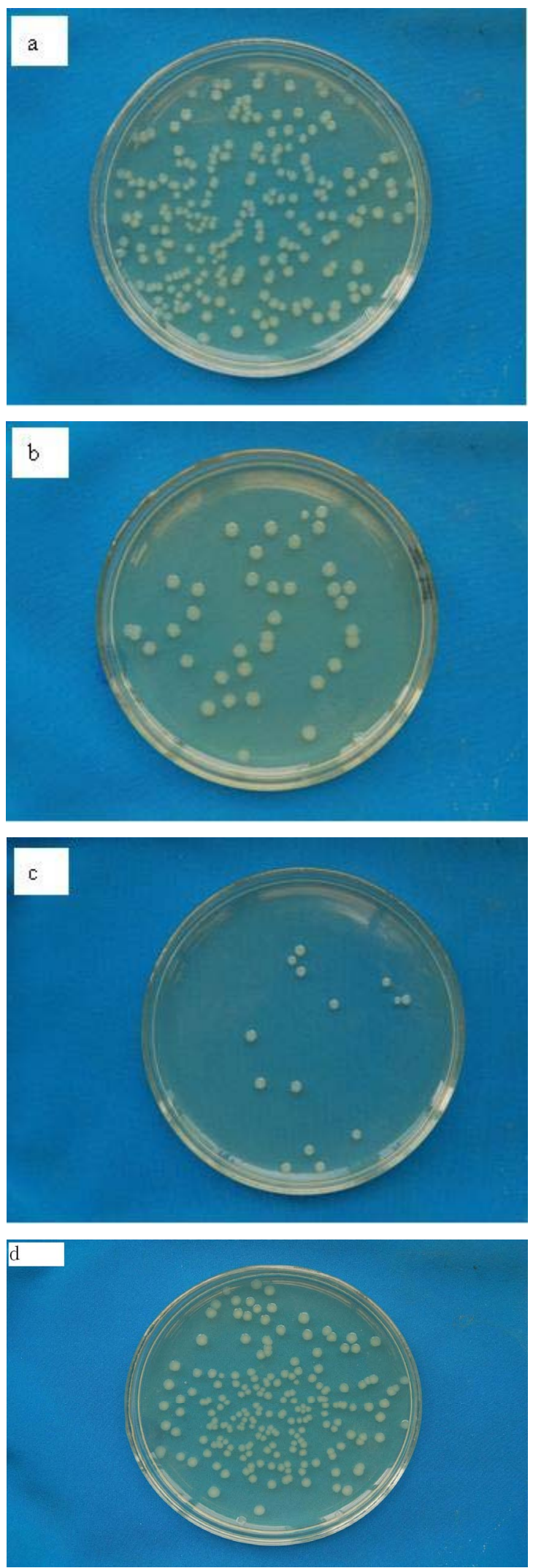

Figure 6. Bacteria adherent number on different PVC surface under dark condition. a) neat PVC; b) $\mathrm{ZnO} / \mathrm{PVC}$; THF-ZnO/PVC; d) initial number.

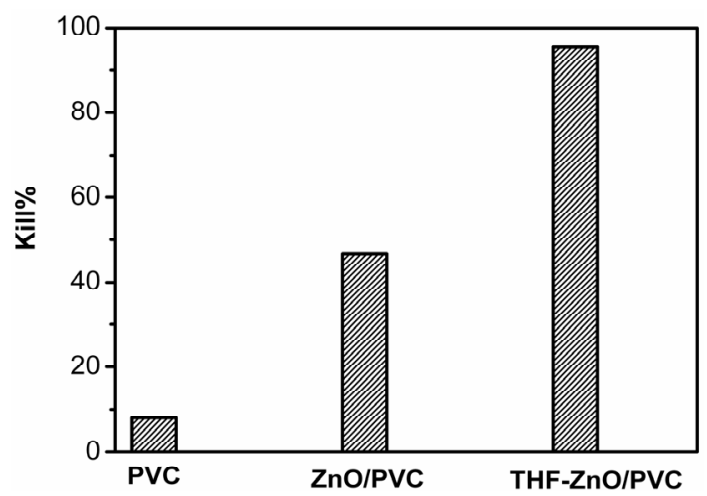

Figure 7. Kill percentage of bacteria on the samples under UV irradiation for $150 \mathrm{~min}$.

that the amount of $\mathrm{ZnO}$ on THF-ZnO/PVC is larger than that on $\mathrm{ZnO} / \mathrm{PVC}$. Under UV irradiation, the amount of electron and hole produced on THF-ZnO/PVC were higher than that on $\mathrm{ZnO} / \mathrm{PVC}$ that resulted in higher concentration of radicals $\left(\mathrm{O}_{2} \bullet\right.$ and $\left.\mathrm{HO} \bullet\right)$ on THF- $\mathrm{ZnO}$ / PVC.

\section{Conclusion}

This work infers that the antibacterial properties of medical-grade PVC material can be enhanced by coating with $\mathrm{ZnO}$. After pretreatment by THF-PVC solution and subsequently coated with $\mathrm{ZnO}$, the PVC surface can not only inhibit the growth of bacteria on dark conditions effectively but also kill bacteria under UV irradiation. The result provides a convenient method that can enhance the adhesive strength and the amount of inorganic oxide film coated on organic materials. It is also easy to operate and can be applied in various substrates.

\section{Acknowledgements}

This work was financially supported by the NSFC (Grants Nos. 21003021, 21173044 and 21203029), the great Science and Technology Project of Fujian Province of P. R. China (2012Y4003), the National Science Foundation for Fostering Talents in Basic Research of China (No. J1103303), and National Basic Research Program of China (973 Program, No. 2012CB722607) and the Science and Technology project of Fuzhou University (2011-XQ-09).

\section{REFERENCES}

[1] S. Lakshmi, S. S. Pradeep and J. A. Kumar, "Bacterial Adhesion onto Azidated Poly (Vinyl Chloride) Surfaces," Journal of Biomedical Materials Research, Vol. 61, No. 1, 2002, pp. 26-32. http://dx.doi.org/10.1002/jbm.10046.abs

[2] P. Vergidis and R. Patel, "Novel Approaches to the Diagnosis, Prevention, and Treatment of Medical Device-Associated Infection," Infectious Disease Clinics of North 
America, Vol. 26, No. 1, 2012, pp. 173-186. http://dx.doi.org/10.1016/j.idc.2011.09.012

[3] D. S. Jones, J. G. McGovern and D. A. Woolfson, "Role of Physiological Conditions in the Oropharynx on the Adherence of Respiratory Bacterial Isolates to Endotracheal Tube Poly (Vinyl Chloride)," Biomaterials, Vol. 18, No. 6, 1997, pp. 503-510. http://dx.doi.org/10.1016/S0142-9612(96)00170-6

[4] Y. H. An and J. R. Friedman, "Prevention of Sepsis in Total Joint Arthroplasty," Journal of Hospital Infection, Vol. 33, No. 2, 1996, pp. 93-108. http://dx.doi.org/10.1016/S0195-6701(96)90094-8

[5] Y. H. An and J. R. Friedman, "Concise Review of Mechanisms of Bacterial Adhesion to Biomaterial Surfaces," Journal of Biomedical Materials Research, Vol. 43, No. 3, 1998, pp. 338-348.

http://dx.doi.org/10.1002/(SICI)1097-4636(199823)43:3 \%3C338::AID-JBM16\%3E3.0.CO;2-B

[6] A. G. Gristina, "Biomaterial-Centered Infection: Microbial Adhesion versus Tissue Integration," Science, Vol. 237, No. 4822, 1987, pp. 1588-1595. http://dx.doi.org/10.1126/science.3629258

[7] A. G. Gristina, C. D. Hobgood and L. X. Webb, "Adhesive Colonization of Biomaterials and Antibiotic Resistance," Biomaterials, Vol. 8, No. 6, 1987, pp. 423-426. http://dx.doi.org/10.1016/0142-9612(87)90077-9

[8] N. P. Desai, S. F. A. Hossainy and J. A. Hubbei, "Surface-Immobilized Polyethylene Oxide for Bacterial Repellence," Biomaterials, Vol. 13, No. 7, 1992, pp. 417420. http://dx.doi.org/10.1016/0142-9612(92)90160-P1

[9] K. D. Park, Y. S. Kim and D. K. Hun, "Bacterial Adhesion on PEG Modified Polyurethane Surfaces," Biomaterials, Vol. 19, No. 7-9, 1998, pp. 851-859. http://dx.doi.org/10.1016/S0142-9612(97)00245-7

[10] Z. Zdanowski, B. Koul and E. Hallberg, "Inflence of Heparin Coating on in Vitro Bacterial Adherence to Poly (Vinyl Chloride) Segments," Journal of Biomaterials Science, Polymer Edition, Vol. 8, No. 11, 1997, pp. 825832. http://dx.doi.org/10.1163/156856297X00029

[11] D. J. Balazs, K. Triandafillu and Y. Chevolot, "Surface Modification of PVC Endotracheal Tubes by Oxygen Glow Discharge to Reduce Bacterial Adhesion," Surface and Interface Analysis, Vol. 35, No. 3, 2003, pp. 301-309. http://dx.doi.org/10.1002/sia.1533

[12] K. Triandafillu, D. J. Balazs and B. D. Aronsson, "Adhesion of Pseudo-Monas Aeruginosa Strains to Untreated and Oxygen-Plasma Treated Poly (Vinyl Chloride) (PVC) from Endotracheal Intuba-tion Devices," Biomaterials, Vol. 24, No. 8, 2003, pp. 1507-1518. http://dx.doi.org/10.1016/S0142-9612(02)00515-X

[13] T. J. Whang, M. T. Hsieh and H. H. Chen, "Visible-Light Photocatalytic Degradation of Methylene Blue with Laser-Induced Ag/ZnO Nanoparticles," Applied Surface Science, Vol. 258, No. 7, 2012, pp. 2796-2801. http://dx.doi.org/10.1016/j.apsusc.2011.10.134

[14] W. K. Ho, J. C. Yu and S. C. Lee, "Photocatalytic Activ- ity and Photo-Induced Hydrophilicity of Mesoporous $\mathrm{TiO}_{2}$ Thin films Coated on Aluminum Substrate," Applied Catalysis B: Environmental, Vol. 73, No. 1-2, 2007, pp. 135-143. http://dx.doi.org/10.1016/j.apcatb.2006.06.019

[15] H. X. Lin, Z. T. Xu and X. X. Wang, "Photocatalytic and Antibacterial Properties of Medical-Grade PVC Material Coated With $\mathrm{TiO}_{2}$ Film," Journal of Biomedical Materials Research, Vol. 87, No. 2, 2008, pp. 425-431. http://dx.doi.org/10.1002/jbm.b.31120

[16] W. Y. Su, S. H. Wang and X. X. Wang, "Plasma PreTreatment and $\mathrm{TiO}_{2}$ Coating of PMMA for the Improvement of Antibacterial Properties," Surface and Coatings Technology, Vol. 205, No. 2, 2010, pp. 465-469. http://dx.doi.org/10.1016/j.surfcoat.2010.07.013

[17] Y. Li, W. Zhang and J. F. Niu, "Mechanism of Photogenerated Reactive Oxygen Species and Correlation with the Antibacterial Properties of Engineered Metal-Oxide Nanoparticles," ACS Nano, Vol. 6, No. 6, 2012, pp. 51645173. http://dx.doi.org/10.1021/nn300934k

[18] A. Thill, O. Zeyons, O. Spalla and F. Chauvat, "Cytotoxicity of $\mathrm{CeO}_{2}$ Nanoparticles for Escherichia coli. PhysicoChemical Insight of the Cytotoxicity Mechanism," Environmental Science \& Technology, Vol. 40, No. 19, 2006, pp. 6151-6156. http://dx.doi.org/10.1021/es060999b

[19] K. H. Tam, A. B. Djurisic, C. M. N. Chan and Y. H. Leung, "Antibacterial Activity of $\mathrm{ZnO}$ Nanorods Prepared by a Hydrothermal Method," Thin Solid Film, Vol. 516, No. 18, 2008, pp. 6167-6174. http://dx.doi.org/10.1016/j.tsf.2007.11.081

[20] N. Jones, B. Ray, K. T. Ranjit and A. C. Manna, "Antibacterial Activity of $\mathrm{ZnO}$ Nanoparticle Suspensions on a Broad Spectrum of Microorganisms," FEMS Microbiology Letters, Vol. 279, No. 1, 2008, pp. 71-76. http://dx.doi.org/10.1111/j.1574-6968.2007.01012.x

[21] Y. Yang, H. Zhang, P. Wang and Q. Zheng, "The Influence of Nano-Sized $\mathrm{TiO}_{2}$ Fillers on the Morphologies and Properties of PSF UF Membrane," Journal of Membrane Science, Vol. 288, No. 1-2, 2007, pp. 231-238. http://dx.doi.org/10.1016/j.memsci.2006.11.019

[22] R. A. Damodara, S. J. Youa and H. H. Chou, "Study the Self Cleaning, Antibacterial and Photocatalytic Properties of $\mathrm{TiO}_{2}$ Entrapped PVDF Membranes," Journal of Hazardous Materials, Vol. 172, No. 2-3, 2009, pp. 1321-1328. http://dx.doi.org/10.1016/j.jhazmat.2009.07.139

[23] S. W. Liu, C. Li and J. G. Yu, "Improved Visible-Light Photocatalytic Activity of Porous Carbon Self-Doped ZnO Nanosheet-Assembled Flowers," Cryst Eng Comm, Vol. 13, No. 7, 2011, pp. 2533-2541. http://dx.doi.org/10.1039/c0ce00295j

[24] M. Bekbolet, "Photocatalytic Bactericidal Activity of $\mathrm{TiO}_{2}$ in Aqueous Suspensions of E. coli," Water Science and Technology, Vol. 35, No. 11-12, 1997, pp. 95-100. http://dx.doi.org/10.1016/S0273-1223(97)00241-2 